S. Suprunenko,

$P h D$ in Economics, Department of Management, University of the State Fiscal Service of Ukraine

ORCID ID:0000-0002-4585-3440

\title{
TAX PLANNING AS ONE OF THE FUNCTIONAL STAGES OF THE REGIONAL TAXATION MANAGEMENT PROCESS
}

\author{
С. А. Супруненко, \\ к. е. н., доцент кафедри менеджменту, Університет державної фіскальної служби Украӥни
}

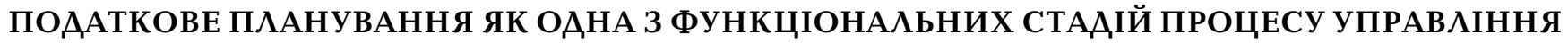
РЕГІОНААЬНИМ ОПОААТКУВАННЯМ

The article reveals the importance of tax planning as one of the most important functional stages of the process of regional tax management, whose main purpose is to analyze the receipt of taxes, tendencies and factors for the development of their tax bases, and on this basis the economic justification of qualitative and quantitative parameters of budgetary allocations in the budget within the framework of the tax concept, formed with regard to the specifics of the regional paradigm of socio-economic development; the analysis of the revenue part of the Consolidated Budget of Ukraine for 2014-2018 and its structure, the tendency is revealed that the priority budget-forming role belongs to tax revenues, which make $81 \%$ on average for the studied period and this trend in Ukraine has become.

The implementation of tax planning in the system of state (regional) regulation of economy in Kyiv region is considered, it is determined that the tax actions of the state will allow it not only to ensure proper functioning, but also to use its resources and instruments of influence to achieve the goals of economic development of the region. Performance of planned tax revenues of Kyiv region is positive, given that tax planning has been properly implemented in practice.

It is determined that the main tasks of tax planning are: forecasting the socio-economic needs of the region as a whole and in terms of territories; the level of inflation, price indices and other; assessment of the region's aggregate income, its economic, financial and tax potential; taking into account the economic growth rate of the region.

Tax planning is based on a prospective assessment of the profitability of territories and terrain. One of the effective tools used to make this estimate is to forecast tax revenue based on a preliminary estimate of the gross regional product.

The article proposed in the implementation of the tax planning process, focused on the development of effective options for establishing local taxes and fees that will allow a guaranteed replenishment of the revenue part of the regional budget, can be used in forming the tax concept of the region.

У Статті розкрито значення податкового планування як однієї 3 найважАивіших функціональних Стадій процесу управління регіональним оподаткуванням, головне призначення якого полягає в аналізі надходження податків, тенденцій $і$ чинників розвитку їх податкових баз і на цій основі економічного обгрунтування якісних і кількісних параметрів бюджетних призначень по податках і зборах у рамках податкової концепції, сформованої з урахуванням специфіки регіональної парадигми соціально-економічного розвитку; проведено аналіз дохідної частини Зведеного бюджету України за 2014-2018 рр. та його структурУ, виявлено тенденцію, що пріоритетна бюджетоутворююча роль належить Податковим надходЖенням, які становлять $81 \%$ у середньому за досліджуваний період та така тенденція в Україні стала. 
Розглянуто здійснення податкового планування в системі державного (регіонального) регулювання економіки у Київькій області визначено, що податкові, дї держави дадуть змогу їй не лише забезпечувати належне функціонування, а й використовувати свої ресурси та інструменти вПливу дАя досягнення цілей економічного розвитку регіону. Показник виконання запланованих Податкових надходжень КиївСької області є Позитивним з огляду на те, що податкове планування було коректно реалізовано на практиці.

Визначено, що основними завданнями Податкового ПАанування є: Прогнозування Соціально-економічних потреб регіону загалом і в розрізі територій; основних соціально-економічних параметрів: рівня інфляції, індексів цін та інших ринкових індикаторів; оцінка сукуПногодоходу регіону, його економічного, фінансового і на цій основі податкового потенціалів; прогнозування обсягів податкових надходЖень у регіоні за видами податків з урахуванням темпів економічного зростання регіону.

Запропоновано в Статті здійснення процесу податкового пАанування, орієнтованого на розробку ефективних варіантів встановлення місцевих податків і зборів, що,дозволить гарантоване поповнення дохіАної частини регіонального бюджету, можуть бути використані під час формування податкової концепціі регіону.

Key words: taxes, tax system, economic management, consolidated budget, state budget, regional budget, tax planning, budgetary relations, decentralization, territorial community, tax base, budget-forming role.

Ключові слова: податки, податкова система, управління економікою, зведений бюджет, державний бюджет, обласний бюджет, податкове планування, бюджетні відносини, дечентралізачіл, територіальна громада, податкова база, бюджетоутворююча роль.

\section{FORMULATION OF THE PROBLEM}

The tax system in place in Ukraine performs mainly a fiscal function, not a regulatory or a stimulating one, or even a managerial one. The efforts of most economists and governing bodies of the fiscal process are aimed at finding forms and methods of filling the state budget by introducing new taxes and payments, changing tax rates, improving the payments of payers to the budget.

At the same time, insufficient attention is paid to the study of factors and methods of management and regulation, such as resource efficiency, production and sales of products and services, cost, sectorial and regional structure of economies and regions, profitability, intensification of production and inflation, which determine the size of production by enterprises and industries, which is the main source of revenue.

There are also no clear methodological approaches to the formation and functioning of the mechanism of planning of revenues to all budgets, namely tax planning, which results in excessive centralization in the formation of budget resources, insufficient elaboration of the issues of effective and efficient method of budgeting at all levels aimed at rational management and regulation processes on the ground and in the country as a whole.

The main source of revenue for all levels of budgets should be own revenues, including local taxes and fees. Therefore, enhancing the role of tax planning in ensuring the rational collection of taxes and fees as a national and local increase in their share of revenues is the main focus of strengthening budgets at all levels and extending the financial autonomy of the respective territories.

Against this background, it is necessary to ensure that tax planning is more effective and that the potential for tax potential growth is identified.

The peculiarity of the tax system in Ukraine is its volatility, which is primarily due to the instability of tax legislation. Therefore, when setting taxes and charges at the local level, the authorities should take this specific feature into account and implement the principle of maximum mobility and flexibility [10-12].
Therefore, there is an urgent need to improve existing and develop new methods of regulation of the fiscal process that would help optimize fiscal relations and relationships, identify factors and reserves of revenue growth, make sound management decisions based on various calculations and plans. This will allow at a different scientific level, taking into account the combination of coordination ties in the fiscal system to approach the solution of a whole complex of insufficiently regulated problems, as well as to create adequate new conditions and more effective instrumental management methods using such component as tax planning for rational planning. and the development of both the regional economy and the state as a whole. All this defines and confirms the necessity and relevance of this research.

\section{ANALYSIS OF RECENT RESEARCH AND PUBLICATIONS}

The basis of the study was the work of domestic and foreign authors.

Foreign economists studied the problems of taxation and tax management: A. Laffer, E. J. Dolan, J. Keynes, S. Fisher, R. Dornbush, R. Schmallenzi, etc.

Issues of formation of taxation adequate to market transformation processes, as well as its further development and reform, problems of public administration of taxation with illumination of a number of problems of tax planning, are devoted to publications in the domestic economic literature in the works Krisovatyi A., Kizima A., Masva V., Shvai V., Shvai, Andrushchenko V., Bondaruk T., Varnalia Z., Vishnevsky V., Vasylika O., Danilova O., Zakharina S., Efimenko T., Ivanishina O., Ivanova Y., Lunina I., Melnik V., Miller P., Onishko S., Oparina V., Skripnik A., Tarangul L., Fedosova V., Yuri S. and others.

Despite the fact that almost all authors agree that taxation is an integral part of stabilizing the economy, and tax revenues are the most important component of the revenue side of the budget, there is no single methodology for forming an effective tax planning system in the region. In this regard, there was a practical need for the development of tax planning of the regional aspect, which is 
Table 1. Revenue structure of the Consolidated Budget of Ukraine in 2014-2018,\%

\begin{tabular}{|l|l|l|l|l|l|}
\hline \multirow{2}{*}{$\begin{array}{c}\text { Chign/ } \\
\text { Characteristic }\end{array}$} & \multicolumn{5}{|c|}{ Year } \\
\cline { 2 - 6 } & $\mathbf{2 0 1 4}$ & $\mathbf{2 0 1 5}$ & $\mathbf{2 0 1 6}$ & $\mathbf{2 0 1 7}$ & $\mathbf{2 0 1 8}$ \\
\hline \multicolumn{5}{|c|}{$\begin{array}{c}\text { Structure of revenues of the Consolidated Budget of Ukraine } \\
\text { by type of budget,\% }\end{array}$} \\
\hline National budget & 77,8 & 81,5 & 78,2 & 77,4 & 77,8 \\
\hline Local budgets & 22,2 & 18,5 & 21,8 & 22,6 & 22,2 \\
\hline \multicolumn{5}{|c|}{ Structure of revenues of the Consolidated Budget of Ukraine, } \\
by type of income \%
\end{tabular}

Source: Created by the author based on [21; 22].

of particular importance for the development of the economy of the region.

The goal of the article is to disclose the importance of tax planning in the process of managing regional taxation and to provide recommendations for its rational and effective application in the formation of the tax concept of the region.

\section{PRESENTING MAIN MATERIAL}

The state budget of the state and local budgets correspond to each other with the size of the total income of the society and are characterized by their own revenue and expenditure parts, on the ratio of which the stability and dynamics of transformational transformations in the economy depend to a great extent. This leads to a study of increasing sources of budget revenue generation, revealing the special role of the tax component in this process.

In the course of the analysis of the structural component of the revenue part of the Consolidated Budget of Ukraine for 2014-2018 (Table 1), the following tendency was revealed: $22 \%$ in the structure of the Consolidated Budget are local budgets; on average during the period under review the priority budget-forming role belongs to tax revenues, which make up $81 \%$ on average over the period under study, and this trend in Ukraine has become.

The study of the problem of increasing the revenue share of budgets of all levels in the economy of Ukraine suggests that the main place in the system of economic management methods belongs to local budgets, although their share $(22 \%)$ is not significant in the Consolidated Budget of Ukraine. How ever, they play an active role in ensuring the integrated development of individual regions, optimal territorial reproductive proportions, and improving the standard of living of the population. This is one of the main channels of bringing the results of social production to the population. Local budgets, like other economic categories, are deliberately used by public authorities to solve socioeconomic problems and are characterized by:

1) a broad sphere of influence, as budgetary relations permeate all sides of the territorial reproduction process;

2) the high degree of efficiency caused by the redistributive nature of a given economic category;

3) flexibility, because the system of budgetary management methods is formed not as a given once and for all a system of levers, but is a dynamic, constantly developing their totality, transformed in accordance with the change of goals and objectives of regional and local development, especially in the conditions of decentralization [6;13].

The economic essence of local budgets is manifested in their purpose. They perform the following functions: formation of monetary funds, which is a financial support to the activities of local authorities; the distribution and use of these funds among sectors of the economy; control over
Table 2. Structure of budget revenues of the Kyiv region 2014-2018\%

\begin{tabular}{|l|l|l|l|l|l|}
\hline \multirow{2}{*}{ Indicator } & \multicolumn{5}{c|}{ Year } \\
\cline { 2 - 7 } & $\mathbf{2 0 1 4}$ & $\mathbf{2 0 1 5}$ & $\mathbf{2 0 1 6}$ & $\mathbf{2 0 1 7}$ & $\mathbf{2 0 1 8}$ \\
\hline Total income & 100 & 100 & 100 & 100 & 100 \\
\hline Tax revenues & 43,4 & 37,7 & 44,7 & 46,7 & 46,5 \\
\hline Non-tax revenues & 6,0 & 6,8 & 7,6 & 5,6 & 4,9 \\
\hline Income from capital operations & 0,61 & 0,52 & 0,46 & 0,41 & 0,47 \\
\hline $\begin{array}{l}\text { From the European Union, foreign } \\
\text { governments, international } \\
\text { organizations, donor institutions }\end{array}$ & - & - & - & - & 0,001 \\
\hline Trust Funds & & & & & \\
\hline Official transfers from public authorities & 50,2 & 54,9 & 47,1 & 47,2 & 48,1 \\
\hline
\end{tabular}

Source: Created and calculated by the author on the basis of $21-23$.

the financial and economic activity of enterprises, organizations and institutions under the authority of local authorities [14-16].

Strengthening local budgets contributes to expanding their regulatory and stimulating impact, creates conditions for more active influence on territorial socio-industrial infrastructure [20].

The processes of decentralization have made fundamental changes in the process of forming the revenues of the budget system of Ukraine: as the main source of budget revenues at all levels are determined tax payments and receipts.

All businesses, depending on the type of activity, pay certain types of taxes and fees.

The right to set local taxes and fees is enshrined in Art. 143 of the Constitution of Ukraine [9] by bodies of local self-government. Thus, according to paragraph 24 of Part 1 of Art. 26 of the Law on Local Self-Government, these issues are solved exclusively in plenary sessions of the village, settlement, city council [18].

The specific list of taxes and fees that are part of the income of the general fund of the budgets of the united territorial communities, which are created in accordance with the law and the perspective plan of formation of the territories of the communities, are defined by Art. 64 and 691 of the Budget Code of Ukraine [3]. The whole range of relations arising in the field of taxation and levying is regulated by the Tax Code of Ukraine (CCU) [17].

Local taxes and fees, which are required to be paid in the territories of the respective territorial communities, apply to the local community. They are set in accordance with the list and within the limits of the maximum rates determined by the TAC.

Local governments, when planning the development of their infrastructure, communities, and so on, consciously or even subconsciously apply tax planning.

Tax planning as one of the functional stages of the process of regional tax management, whose main purpose 
Table 3. Implementation of tax revenues of the budget of the Kyiv region

2014-2018

\begin{tabular}{|l|l|l|l|l|l|}
\hline \multicolumn{1}{|c|}{ Tax revenues } & \multicolumn{5}{|c|}{ Year } \\
\cline { 2 - 6 } & \multicolumn{1}{|c|}{2014} & \multicolumn{1}{|c|}{2015} & \multicolumn{1}{c|}{2016} & \multicolumn{1}{c|}{2017} & \multicolumn{1}{c|}{2018} \\
\hline Plan, thousand UAH. & 805987,0 & 700714,9 & 955057,4 & 1443801,5 & 1881896,9 \\
\hline Fact, thousand UAH & 840038,5 & 787324,9 & 1141472,7 & 1507464,1 & 1934721,3 \\
\hline$\%$ execution & 104,2 & 112,4 & 119,5 & 104,4 & 102,8 \\
\hline $\begin{array}{l}\text { \% of tax revenue in total } \\
\text { budget revenue (actual } \\
\text { implementation) }\end{array}$ & 91,56 & 83,98 & 79,9 & 92,23 & 94,38 \\
\hline
\end{tabular}

Source: Created and calculated by author based on 5.

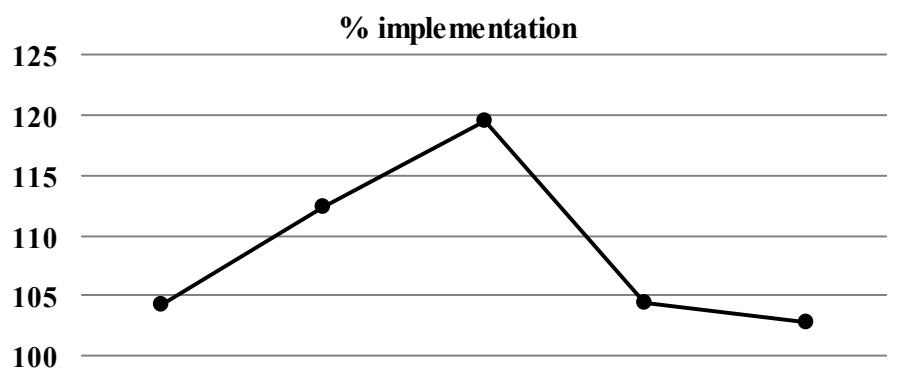

95

90

$\begin{array}{lllll}2014 & 2015 & 2016 & 2017 & 2018\end{array}$

Fig. 1. Status of implementation of the revenue part of the budget of the Kiev region in the part of tax revenues in 2014-2018, \%

Source: Created by the author, based on Table 3 .

is to analyze the receipt of taxes, trends and factors of development of their tax bases and on this basis economic justification of the qualitative and quantitative parameters of budgetary appointments for taxes and fees within the tax concept, formed taking into account the specifics of the regional paradigm of socio-economic development of the region and the region, the state as a whole $[7 ; 8 ; 11 ; 19]$.

Tax revenues occupy a leading place in the revenue structure of all units of the budgetary system, as evidenced by the data in Table 1 .

At the same time, the data show that the share of tax revenues in all levels of the budget system has increased over the years.

Hence the importance of sound tax planning, as well as tax revenues, given their specific budgetary role in the regulation of the economy of the state as a whole and of the regions in particular.

Thus, on the one hand, the economic and social wellbeing of the regions depends directly on the efficiency of the operation of regional tax planning, which is expressed in the planning of sufficient intensity and stability of tax flows, increase of tax base (fiscal component), the implementation of the proper social components of the tax system, on the other, from the objective assessment and the degree of realization of the tax potential of the region [24].

In the context of our study, Kyiv region was selected for analysis of tax planning in the system of state regulation of the economy; it is the administrative-territorial unit within Ukraine which is $4.7 \%$ of the country. In terms of territory size, Kyiv region ranks 8 th among other regions of Ukraine [23].

The expediency of the analysis of the Kiev region in the context of our study is explained by the fact that the Kyiv region is around the capital region, in the center of the territory of which is Kyiv - the capital of Ukraine, a powerful political, business, industrial, scientific, technical, transport and cultural center of the country. with close commercial and social ties.

Implementation of tax planning in the system of state (regional) regulation of the economy in the Kiev region determines that the tax actions of the state will allow it not only to ensure proper functioning, but also to use its resources and instruments of influence to achieve the goals of economic development [25].

Tax planning initiatives have a twofold effect on the growth of the region's economy. Thus, there is a need for a detailed study of the impact of used tax planning methods on the amount of taxes and fees [25]. Consider the structure of budget revenues of the Kiev region (Table 2).

Thus, in the Kyiv region in 2014-2018, their share of tax revenues in all incomes is on average $43 \%$, in turn, official transfers from public administration $-50 \%$ (Table 2 ). indicating that economic and social growth is not possible.

As you can see, the share of tax revenues far outweighs the share of non-tax revenues. Thus, in 2018, the share of tax revenues in the total structure was about $46.5 \%$, while non-tax revenues $-5 \%$. However, there is a trend, though not a significant decrease in transfers by almost $1 \%$ in 2018 compared to 2017 , by $2 \%$ in 2018 compared to 2014 .

For details of the information in table 3 . the dynamics of tax revenues of the Kyiv region in 2014-2018 are shown.

To determine the level of implementation of tax planning in Fig. 1 shows the state of implementation of the revenue part of the budget of the Kiev region in the part of tax revenues in 2014-2018.

In Fig. 1. it is clear that in $2014-2018$ the actual implementation of the revenue part of the budget of the Kyiv region in terms of tax revenues had positive values, which are increasing every year. In 2017, this figure decreased slightly to $104.4 \%$ of the planned amount of revenues, but this indicator is positive, given that tax planning was properly implemented in practice [25].

In view of all the above, it is quite right to state that tax planning is the most important and relevant part of state regulation of the economy and rational budgeting of all levels and local ones.

In addition, since the tax base is currently gaining momentum, it is especially important to properly design the tax planning process to minimize the possibility of raising budget deficits [25].

The main problem of tax planning is the economic justification in terms of tax sources of qualitative and quantitative parameters of budgetary purposes, as well as programs of socio-economic development within the existing regulatory framework.

The solution of this problem will lead to the implementation of two relatively independent areas: the definition of a contingent of major taxes and intergovernmental budget regulation. Tax planning is based on a prospective assessment of the profitability of territories and terrain. One of the effective tools used to make this estimate is to forecast tax revenue based on a preliminary estimate of the gross regional product $[1 ; 2 ; 4]$.

In this context, the main tasks of tax planning are: forecasting the socio-economic needs of the region as a whole and in terms of territories; the main socio-economic parameters: the level of inflation, price indices and other market indicators; assessment of the region's aggregate income, its economic, financial and tax potential; forecasting the amount of tax revenues in the region by 
types of taxes, taking into account the economic growth rate of the region.

Therefore, in the context of the study, tax planning is considered as the most important element and instrument of formation of the revenue part of the budget of the region (region), so it involves the introduction of different mathematical methods to improve the forecasting of tax revenues. In the context of the tight fiscal policy of the state against the background of the ongoing economic crisis and the reduction of material production, tax planning allows to determine the expenditure items of the budget to the extent necessary for the implementation of social and other programs of the authorities and at the same time avoiding budget deficits.

In this regard, the initial component of tax planning should be to determine the tax base, which is a value, physical or other characteristic of the tax object and is established for each type of tax. The tax base must be calculated in regional, regional and local terms, taking into account the sectoral structure for each type of tax. In doing so, tax planning should be based on the results of the analysis of the implementation of current tax obligations, as well as monitoring and forecasting the macroeconomic situation in the regions and regions.

This situation is explained not so much by the efficiency of tax authorities as by the existing tax base and the corresponding movement of financial flows, which necessitates the use of an individual approach in calculating the tax base for each region and region.

\section{CONCLUSIONS FROM THIS STUDY AND PROSPECTS FOR FURTHER EXPLORATION IN THIS AREA}

In the course of the study it was found that the formation of the revenue part of budgets of all levels depends on many joint factors, in particular: socio-economic development of the country, regions and regions.

It is determined that the use of effective budgeting strategies in the region and the region is determined by the fact that the size of the budget revenues is influenced by two groups of factors. The first group includes the number and types of taxes, the magnitude of tax rates, collection of tax payments, the crisis of payments, arrears of wages, barter transactions, which collectively represent the mechanism of withdrawal of part of income in the budget. The effective functioning of tax planning largely depends on the budget revenues, which determines the need for its further improvement. The second group includes the magnitude and efficiency of the use of factors of production, the volume of production and sales of products and services, the sectoral, cost and regional structure of the economy, the level of profitability of production, inflation, intensification of production. Recognizing the importance of the first group of factors, it should be emphasized that the decisive impact on budget revenues and reserves for their growth is made by the second group.

Prospects for further research: finding and building optimal cooperation in the process of regulating the economy at the regional, regional and local levels in the context of constant reforms in Ukraine.

To improve the methods of managing the budget process, to increase the validity of management decisions based on various calculations in the future studies, it is planned to use the method of simulation.

Мітература:

1. Актуальні проблеми теорії та практики оподаткування: монографія / [ С.С. Брехов, $\Lambda . \Lambda$. Тарангул та ін.]; за ред. А.М. Новицького, В.В. Аисенка, К.І. Швабія; Мін-во доходів і зборів України, Нац. ун-т державної податкової служби України, НАЦ з проблем оподаткування. - Ірпінь: НУАПСУ, 2013. - 556 с.

2. Андрущенко В.А. Економічні та позаекономічні аспекти оподаткування / В.А. Андрущенко, Ю.І. $\Lambda$ яшенко // Фінанси України. - 2005.—№ 1. - С. 36-44.
3. Бюджетний кодекс України: Закон України від 08.07.2010 р. № 2456-VI [Електронний ресурс]// Вiдомості Верховної Ради України (ВВР), 2010, № 50-51Режим доступу: http://zakon3.rada.gov.ua/laws/show/ 2456-17 (дата звернення 29.04. 2020p.). - Назва з екрана.

4. Бюджетування результативності / Річард Ю. Зоді, Скот М. Аоуренс, Аональд П. Аейсі та ін.- К.: Ін-т держ. упр., Політехн. ін-т і УН-т штату Вірджинія Блексбер, 1987.- 147 c.

5. Виконання обласного бюджету Київської області. Київська обласна державна адміністрація [Електронний peсурс]. - Режим доступу: http://koda.gov.ua/oblderzhadministratsija/struktura/strukturni-pidrozdili-oda/ departament-finansiv/byudzhet/vikonannya-oblasnogobyudzhetu-kiivsk (дата звернення 29.04. 2020 р.). - Назва з екрана.

6. Аержавний бюджет і бюджетна стратегія в умовах економічних реформ: [монографія]: у 4 т. Т. 2: Бюджетна стратегія і державний бюджет 2012: збалансованість, прозорість, реалістичність / [П. П. Андрєєв,

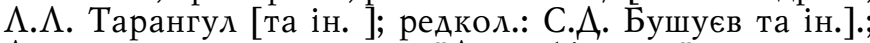
Аерж. навч.-наук. установа "Акад. фін. упр."; за заг. ред. М.Я. Азарова. - К.: АННУ "Акад. фін. упр.", 2011. $911 \mathrm{c}$.

7. Зварич О.В. Податкові надходження: методологія прогнозування: монографія / О.В.Зварич. - К.: Київ. нац. торг.-екон. ун-т, 2013. - 444 с.

8. Иванов Ю.Б. Налоговое планирование: принципы, методы, инструментарий: Монографыя/Ю.Б. Иванов, В.В. Карпова, А.Н. Карпов.-Х.: ИНЖЭК, 2008. 272c.;

9. Конституція України [Електронний ресурс]// Відомості Верховної Ради України (ВВР). - 1996. № 30. - C. 141. - Режим доступу: http://zakon5.rada.gov.ua/laws/show $/ 254 \% \mathrm{D} 0 \% \mathrm{BA} / 96-\% \mathrm{D} 0 \% \mathrm{~B} 2 \% \mathrm{D} 1 \% 80$ (дата звернення 29.04. 2020p.). - Назва з екрана.

10. Крисоватий A.I. Новітня парадигма преференційного оподаткування [текст]: монографія / А.І. Крисоватий, Г.В. Василевська. - К.: Центр учбової літератури, 2013. - 260 с.

11. Крисоватий A.I. Податкові трансформації в $E C$ та податкова політика України в контексті євроінтеграції: моногр./ А.І. Крисоватий, В.М. Мельник, Т.В. Кощук; за ред.А.е.н., проф. А.І. Крисоватого. - Тернопіль: THEУ, 2014. - $236 \mathrm{c}$.

12. Крисоватий A.I., Кізима А.Я., Маслій В.В. Планування та прогнозування податкових надходжень: навч. пос. - Тернопіль: Економічна думка ТНЕУ, 2011. $-260 \mathrm{c}$.

13. Мельник В.М.Аомінанти податків і оподаткування та забезпечення повноти їх дії: дис. А-ра екон. наук: 08.00.08 / В.М. Мельник; Аерж. установа "Інт економіки та прогнозування НАН України". - К., 2007.— 444 арк. Бібліогр.: арк. 422-444.

14. Основи оподаткування: навч. посіб. / авт. кол.:

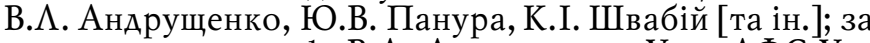

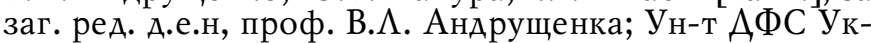
раїни - Ірпінь, 2019. - 134 с. - (Серія "Податкова та митна справа в Україні", т. 126).

15. Планування податкових надходжень: теорія та практика: [монографія]/ П.В. Мельник, $\Lambda . \Lambda$. Тарангул,

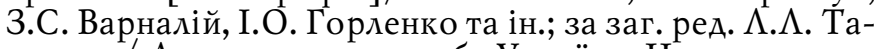
рангул / Аерж. подат. служба України, Нац. ун-т державної податкової служби України. - Ірпінь: НУАПСУ, 2011. - 339 с.

16. Податкова політика України: навч. посіб. / П.В. Мельник, 3.С. Варналій, $\Lambda . \Lambda$. Тарангул [ та ін. ]; за ред.А.е.н., проф. П.В. Мельника; Аерж. подат. адмін. України, НАЦ з проблем оподаткув, НАІ фінансового права. - К.: Знання України, 2010.- 505 с. - (Ао 90-річчя навчального закладу).

17. Податковий кодекс України: Закон України № 2755-VI від 02.12.2010р. [Електронний ресурс]// BBP. 
- 2011. - № № 13-17. Ст. 112 - Режим доступу: http:/ /zakon.rada.gov.ua/cgi-bin/laws/ main.cgi?nreg=2755-17 (дата звернення 29.04. 2020p.). - Назва з екрана.

18. Про місцеве самоврядування в Україні: Закон України від 21 трав. 1997 р. № 280/97-ВР [Електронний ресурс] / Верховна Рада України - Режим доступу: http://zakon4.rada.gov.ua/laws/show/280/97 (дата звернення 29.04. 2020р.). - Назва $з$ екрана.

19. Супруненко С. Податкове планування як засіб гармонізації взаємовідносин держави та суб'єктів господарювання. Економічний аналіз, Вип. 13, Тернопільський національний економічний університет 2013. С. $194-200$.

20. Станкус Т. Місцеві податки і збори / Т. Станкус, Ю. Крот. - Х.: Фактор, 2017. - 80 с. ISBN 978-966-180714-2

21. Статистичний збірник "Бюджет України 2016" підготовлено відділом статистики державних фінансів Аепартаменту державного бюджету Міністерства фінансів України. (дата звернення 16.04.2020 p.) https:/ mof.gov.ua/storage/files/a6d88e3b4e411ca655003eba01eff826.pdf Назва з екрана.

22. Статистичний збірник: "Бюджет України 2018" підготовлено відділом статистики державних фінансів Аепартаменту державного бюджету Міністерства фінансів України. https://mof.gov.ua/ storage/files/Budget $\% 20$ of $\% 20$ Ukraine $\% 202018 \%$ 20 (for \%20website).pdf (дата звернення 13.04.2020р.). Назва з екрана.

23. Стратегія розвитку Київської області на період до 2020 р. від 06.11.2014 № 370 [Електронний ресурс]. Режим доступу: https://surdp.eu/uploads/files/Kyivska_RDS_FINAL_UA.pdf (дата звернення 13.04.2020р.). Назва з екрана.

24. Супруненко С.А. Податкове планування - невід'ємний елемент податкового механізму держави. URL: http:// repository.kpi.kharkov.ua/bitstream/KhPIPress/25948/1/Suprunenko_Podatkove_planuvannia_2016.pdf (дата звернення: 01.04.2020).

25. Супруненко С.А. Податкове планування в системі державного регулювання економіки України: дис... к.е.н.: 08.00.03. / Чернігів. нац. тенолог. ун-т. Чернігів, 2019. 185 c.

\section{References:}

1. Novyts'kyi, A.M. Lysenko, V.V. and Shvabiy, K.I. (2013), Aktual'ni problemy teorii ta praktyky opodatkuvannia [Current issues of theory and practice of taxation], NUDPSU, Irpin', Ukraine.

2. Andruschenko, V.L. and Liashenko, Yu.I. (2005), "Economic and non-economic aspects of taxation", Finansy Ukrainy, vol. 1, pp. 36-44.

3. Verkhovna Rada of Ukraine (2010), "Budget Code of Ukraine", available at: https:// zakon.rada.gov.ua/laws/ show/en/2456-17 (Accessed 25 April 2020).

4. Zodi, R.Yu. Lourens, S.M. and Lejsi, D.P. (1987), Biudzhetuvannia rezul'tatyvnosti [Performance budgeting], In-t derzh. upr., Politekhn. in-t i Un-t shtatu Virdzhyniia Bleksber, Kyiv, Ukraine.

5. Kyiv Regional State Administration (2020), "Execution of the regional budget of Kyiv region. Kyiv Regional State Administration", available at: http:// koda.gov.ua/oblderzhadministratsija/struktura/strukturni-pidrozdili-oda/departament-finansiv/byudzhet/ vikonannya-oblasnogo-byudzhetu-kiivsk. (Accessed 10 April 2020).

6. Andrieiev, P.P. and Taranhul, L.L.(2011), Derzhavnyj biudzhet i biudzhetna stratehiia v umovakh ekonomichnykh reform u $4 \mathrm{t}$. [State budget and budget strategy in terms of economic reforms in 4 vols.], vol. 2, Biudzhetna stratehiia i derzhavnyj biudzhet 2012 : zbalansovanist', prozorist', realistychnist' [Volume 2, Budget Strategy and State Budget 2012: Balance, Transparency, Realism], DNNU "Akad. fin. upr.", Kyiv, Ukraine.
7. Zvarych, O.V. (2013), Podatkovi nadkhodzhennia: metodolohiia prohnozuvannia [Tax revenues: forecasting methodology], Kyiv. nats. torh.-ekon. un-t, Kyiv, Ukraine.

8. Yvanov, Yu.B. Karpova, V.V. and Karpov, L.N. (2008), Nalohovoe planyrovanye: pryntsypy, metody, ynstrumentaryj [Tax planning: principles, methods, tools], YNZhEK, Kharkiv, Ukraine.

9. Verkhovna Rada of Ukraine (1996), "The Constitution of Ukraine", available at: http://zakon5.rada.gov.ua/laws/show/en/254\%D0\%BA/96-\%D0\%B2\%D1\%80 (Accessed 20 April 2020).

10. Krysovatyj, A.I. and Vasylevs'ka, H.V. (2013), Novitnia paradyhma preferentsijnoho opodatkuvannia [The latest paradigm of preferential taxation], Tsentr uchbovoi literatury, Kyiv, Ukraine.

11. Krysovatyj, A.I. Mel'nyk, V.M. and Koschuk, T.V. (2014), Podatkovi transformatsii v YeS ta podatkova polityka Ukrainy v konteksti ievrointehratsii [Tax transformations in the EU and tax policy of Ukraine in the context of European integration], TNEU, Ternopil', Ukraine.

12. Krysovatyj, A.I. Kizyma, A.Ya. and Maslij, V.V. (2011), Planuvannia ta prohnozuvannia podatkovykh nadkhodzhen' [Planning and forecasting of tax revenues], Ekonomichna dumka TNEU, Ternopil', Ukraine.

13. Mel'nyk, V.M. (2007), "Dominants of taxes and taxation and ensuring the completeness of their action", Abstract of Ph.D. dissertation, Economy, Derzh. ustanova "Int ekonomiky ta prohnozuvannia NAN Ukrainy", Kyiv, Ukraine.

14. Andruschenko, V.L. Panura, Yu.V. and Shvabij, K.I. (2019), Osnovy opodatkuvannia [Basics of taxation], Un-t DFS Ukrainy, Irpin', Kyiv, Ukraine.

15. Mel'nyk, P.V. Taranhul, L.L. Varnalij, Z.S. and Horlenko, I.O. (2011), Planuvannia podatkovykh nadkhodzhen': teoriia ta praktyka [Planning of tax revenues: theory and practice], NUDPSU, Irpin', Ukraine.

16. Mel'nyk, P.V. Varnalij, Z.S. and Taranhul, L.L. (2010), Podatkova polityka Ukrainy [Tax policy of Ukraine], Znannia Ukrainy, Kyiv, Ukraine.

17. Verkhovna Rada of Ukraine (2010), "Tax Code of Ukraine", available at: http://zakon.rada.gov.ua/laws/ show/2755-17 (Accessed 20 April 2020).

18. Verkhovna Rada of Ukraine (1997), The Law of Ukraine "On Local Self-Government in Ukraine", available at: https://zakon.rada.gov.ua/laws/show/en/280/97$\%$ D0\%B2\%D1\%80 (Accessed 20 April 2020).

19. Suprunenko, S. (2013), "Tax planning as a means of harmonizing the relationship between the state and business entities", Ekonomichnyj analiz, vol. 13, pp. 194-200.

20. Stankus, T. and Krot, Yu. (2017), Mistsevi podatky i zbory [Local taxes and fees], Faktor, Kharkiv, Ukraine.

21. Ministry of Finance of Ukraine (2017), "Statistical publication "Budget of Ukraine 2016", available at: https:/ mof.gov.ua/storage/files/a6d88e3b4e411ca655003eba01eff826.pdf (Accessed 10 April 2020).

22. Ministry of Finance of Ukraine (2019), "Statistical publication "Budget of Ukraine 2018",available at: https:// mof.gov.ua/storage/files/Budget \%20of\%20Ukraine\%$202018 \% 20$ (for \%20website).pdf (Accessed 10 April 2020).

23. Kyiv Regional State Administration (2014), "Development strategy of Kyiv region for the period up to 2020 ", available at: https:// surdp.eu/uploads/files/ Kyivska_RDS_FINAL_UA.pdf (Accessed 10 April 2020).

24. Suprunenko, S.A. (2016), "Tax planning is an integral part of the state tax mechanism", available at: http:// repository.kpi.kharkov.ua/bitstream/KhPI-Press/25948/ 1/Suprunenko_Podatkove_planuvannia_2016.pdf (Accessed 10 April $20 \overline{20})$.

25. Suprunenko, S.A. (2019), "Tax planning in the system of state regulation of the economy of Ukraine", Abstract of Ph.D. dissertation, Economy, Chernihiv. nats. tenoloh. un-t. Chernihiv, Ukraine.

Стаття надійшла до редакиї 04.05.2020 p. 